\title{
DOAS MEASUREMENTS ABOVE AN URBAN STREET CANYON IN A MEDIUM SIZED CITY
}

\author{
A.G. TRIANTAFYLLOU \\ S. ZORAS* \\ V. EVAGELOPOULOS \\ S. GARAS \\ C. DIAMANTOPOULOS
}

Received: 05/10/07

Accepted: 10/12/07

\author{
Laboratory of Atmospheric Pollution \\ and Environmental Physics \\ Technological Education Institute of West Macedonia \\ Kozani 50100 Greece
}

*to whom all correspondence should be addressed: e-mail: stamatis@airlab.teikoz.gr

\begin{abstract}
The concentrations of ozone, $\mathrm{NO}_{2}$ and $\mathrm{SO}_{2}$ measured by a Differential Optical Absorption Spectroscopy (DOAS) system in the city of Kozani in Northwestern Greece are presented and compared against data from a conventional ground station. This was made in order to assess DOAS performance in a complicated area in terms of sources variety, terrain complexity and meteorological conditions. Measurements of aromatic hydrocarbon substances (benzene, toluene, styrene and xylene) are also presented for air quality purposes.
\end{abstract}

Results between the conventional station and the DOAS system indicated the existence of significant correlations among some of the monitored trace gases, confirming this way the strong compatibility between the two systems. The low values of sulfur dioxide especially during the winter were attributed to the absence of central heating in the most of the buildings due to the use of district heating provided by the Greek Public Power Corporation. The averaged annual benzene and daily toluene concentrations exceeded their legislated limits.

Meteorological parameters remain vital in the development of a clear understanding in DOAS performance due to its ability to cover a wide spatial scale over the open path length.

KEYWORDS: differential optical absorption spectroscopy, DOAS, urban street canyon, ozone, $\mathrm{NO}_{2}, \mathrm{SO}_{2}$, benzene, toluene, p,m-xylene, aromatic hydrocarbons, VOCs.

\section{INTRODUCTION}

Traffic emissions to the atmosphere include volatile organic compounds (VOC) and $\mathrm{NO}_{\mathrm{x}}$ that in the presence of sunlight react photochemically forming ozone. Benzene is primarily emitted from vehicles through catalytic reforming or steam cracking and is emitted in vehicle exhaust as unburned fuel and as a product of combustion (Wu et al., 2006). Toluene is added in order to raise octane rating in gasoline that may be emitted to the air. Formation of ozone depends on the contribution of VOCs to the conversion of $\mathrm{NO}$ to $\mathrm{NO}_{2}$. In specific, they accelerate NO titration with toluene reacting at a faster rate than benzene. Xylenes are more reactive than toluene and therefore, it might be difficult to be detected (Barrefors, 1996).

The formation and accumulation of ozone at ground level is dangerous for people with respiratory diseases (Bernard et al., 2001). The combination of chemical substances and specific meteorological parameters cause the formation of the ground level ozone layer. High temperature, sunlight intensity and increased surface pressure have been proved to help ozone in its formation (Chen et al., 2003). In addition, local circulations (e.g. sea breeze, valley winds) with light (Chiu et al., 2005) or stronger (Kelessis et al., 2006) winds may assist in ozone formation by creating adequate dilution conditions that accelerate photochemical reactions. Wind direction has also been considered as an important factor in the formation of ozone. For example, a petrochemical facility may be responsible for ozone production for a distance of up to $26 \mathrm{Km}$ (Chiu et al., 2005). 
The DOAS technique was developed by Platt and Perner (1979). Although, it avoids the problems with local influences and surface effects with light paths that range over several kilometers producing averaged measured concentrations, DOAS measurements represent relatively large areas at higher levels than people and traffic move. Conventional measurements at ground level are influenced by small sources in their vicinity, surface dry deposition and small-scale wind effects.

In the present study DOAS performance is assessed in a medium sized city surrounded by a complicated area in terms of sources variety (i.e. coal fired power stations operation and urban sources), terrain complexity and meteorological conditions (Evagelopoulos et al., 2005). The basin north of the city of Kozani in northwestern Greece is a heavy industrialized area with power plants and opencast mining operations. It is governed by nocturnal stagnant conditions (Zoras et al., 2006) helping in the production of ozone within the surface boundary layer during sunny mornings. Stack emissions may affect the city under specific meteorological conditions that in combination with urban sources may cause severe air pollution episodes (Triantafyllou et al., 2002a).

Measurements of ozone, $\mathrm{NO}_{2}, \mathrm{SO}_{2}$ and aromatic hydrocarbon substances (benzene, toluene, styrene and p,m-xylene) are presented for air quality purposes. In order to reveal the most important factors in ozone production, DOAS data are analyzed against each other and meteorology experimental measurements (Petrakis et al., 2003). Seasonality and daily fluctuations of the pollutants are also investigated. The effects of meteorological factors on the DOAS performance could also be examined through investigation of indirect environmental parameters that influence pollutant's concentrations due to local meteorological parameters, synoptic conditions and micro scale street canyon flow effects.

\section{AREA AND DATA SET DESCRIPTION}

The basin in the axis of the Greek cities of Kozani and Ptolemais is a heavily industrialised area and can be characterized as a broad, relatively flat bottomed basin surrounded by tall mountains with height ranging from 800 to more than $2000 \mathrm{~m}$ above sea level. It is approximately $50 \mathrm{~km}$ in length and the width ranges from 10 to $25 \mathrm{~km}$. The basin axis has a northwest to southeast direction. Four lignite power stations (PS) are operated by the Greek Public Power Corporation. The power plants lie at about $650 \mathrm{~m}$ above sea level. Kozani is located very close to the basin while being protected from the basin's near surface dust by a hill. Figure 1 shows the topography of the region with the PS. More details on the area can be found elsewhere (Triantafyllou et al., 2002a).

DOAS spectra were recorded using a high-pressure $150 \mathrm{~W}$ xenon lamp. The DOAS (SANOA, Environnement S.A.) system was installed on the roofs of two opposite buildings above the busiest street in the city of Kozani. Figure 2 describes the top of the street canyon covered by the DOAS light path. The emitter and the receptor are located at a height of $10 \mathrm{~m}$ and $15 \mathrm{~m}$, respectively, above ground level covering a distance of $291 \mathrm{~m}$ in length. The span calibration of the DOAS system was performed by introduction of one or more-gas cell with a known high concentration of the gas in interest.

The period of hourly experimental measurements covered the whole year of 2006. Concentrations of $\mathrm{O}_{3}, \mathrm{NO}_{2}, \mathrm{SO}_{2}$, benzene, toluene, $\mathrm{p}, \mathrm{m}$-xylene and styrene have been collected from DOAS measurements. For the same period experimental data of $\mathrm{SO}_{2}, \mathrm{O}_{3}$ and $\mathrm{NO}_{2}$ from a ground surface have also been collected. Meteorological parameters of temperature, solar radiation, humidity, surface pressure and wind speed and direction were obtained from the meteorological station on the roof of the Technological Education Institute (TEI) of West Macedonia. 


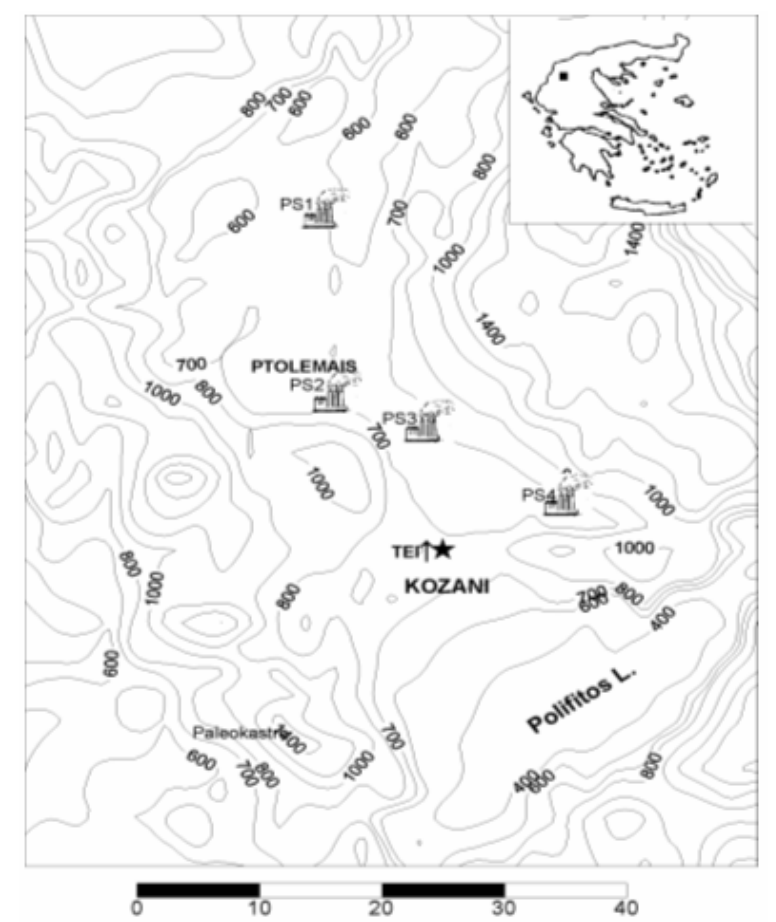

Figure 1. Topography of Kozani Ptolemais basin with the power stations (PS)

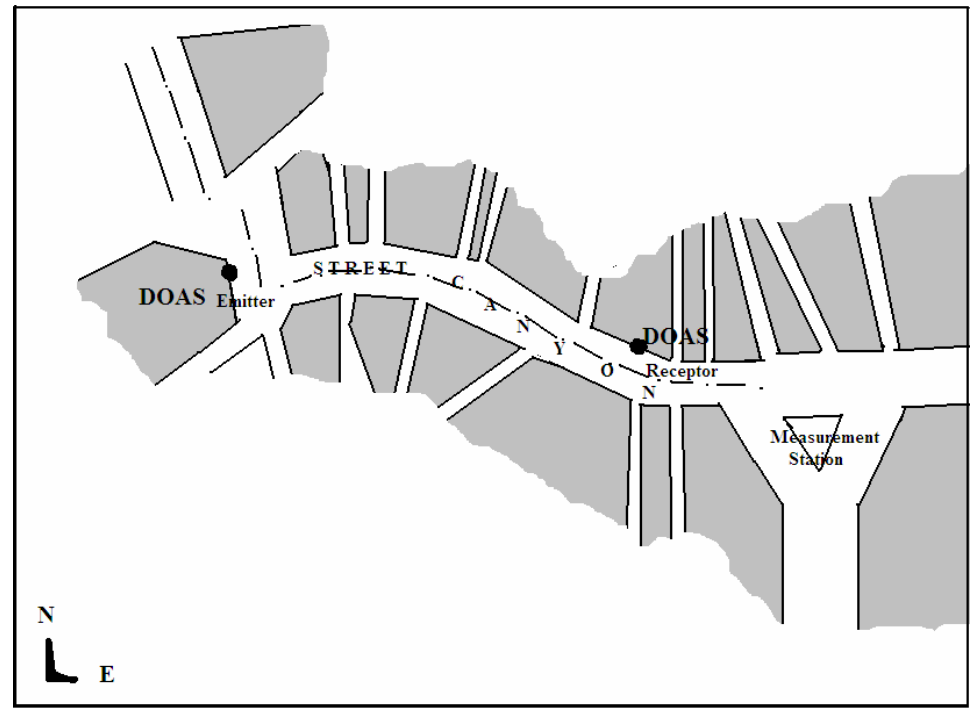

Figure 2. Street canyon covered by DOAS light path

\section{RESULTS}

In Table 1 are shown the basic statistics of experimental data. Measurements from DOAS for ozone and $\mathrm{SO}_{2}$ are in a good agreement with the ground surface station data apart from $\mathrm{NO}_{2}$. From Table 2 the Pearson correlation coefficients of $\mathrm{SO}_{2}$ and $\mathrm{O}_{3}$ between the sampling site and DOAS are 0.89 and 0.63 , respectively. Since the locations of the ground sampling stations are not exactly below the DOAS path, and the DOAS measurements represent averages over paths, one cannot except a full correlation between the two kinds of measurements for $\mathrm{NO}_{2}$.

A very interesting symmetric level has been occurred between ozone and $\mathrm{NO}_{2}$ which follow opposite trends (Figure 3 ) with a correlation coefficient of 0.06 . A steady rise in ozone level is observed with decreased $\mathrm{NO}_{2}$ concentration. The peak concentration of $\mathrm{NO}_{2}$ occurs before the peak of ozone because the photochemical reaction sequence forms $\mathrm{NO}_{2}$ first and then ozone. This hints the favourable photochemical ozone production within the urban complex 
between morning hours depending on the season and 18.00 hours in the afternoon. In general, the correlation between ozone and the primary pollutants benzene, toluene and xylene isomers was low due to their opposite behaviour.

Figure 4 shows the mean hourly pollutants' concentrations on a seasonal and annual basis against wind speed. Relatively high ozone levels are observed during night time due to previous day's conditions that helps in nocturnal ozone build up. This is explained from the low wind speed in the night during transition period combined with stagnant or high surface pressure during night. After sunset the main removal of ozone is through reaction with $\mathrm{NO}_{2}$. High concentrations of primary and secondary pollutants during night may also be attributed to lake breeze from Polifitos (Triantafyllou and Kassomenos, 2002b) that recirculates pollution back to the city. From Figure 4 during daytime, ozone increases with wind speed because fresh oxygen is supplied in the photochemical cycle that reacts with $\mathrm{NO}_{2}$ decreasing its levels. In addition, wind helps in the dilution of the atmospheric mass bringing these way more photochemically reactive molecules under the sunlight's influence. It is also noted that high wind speed favours distant transfer of background ozone from higher levels to the city of Kozani. Moreover, nocturnal accumulation of primary pollutants (VOCs) and NOx from power plants' emissions may impact ozone concentration at DOAS level.

Table 1. Mean daily statistics of experimental data of year 2006

\begin{tabular}{|c|c|c|c|c|c|}
\hline & Mean & Std. Deviation & Range & $\mathbf{N}$ & Location \\
\hline $\mathrm{NO}_{2}\left(\mu \mathrm{g} \mathrm{m}^{-3}\right)$ & 25.33 & 11.81 & $0-89$ & 285 & doas \\
\hline $\mathrm{SO}_{2}\left(\mu \mathrm{g} \mathrm{m}^{-3}\right)$ & 7.99 & 6.66 & $0-117$ & 284 & doas \\
\hline $\mathrm{O}_{3}\left(\mu \mathrm{g} \mathrm{m}^{-3}\right)$ & 32.04 & 12.25 & $0-80$ & 279 & doas \\
\hline Toluene $\left(\mu \mathrm{g} \mathrm{m}^{-3}\right)$ & 15.56 & 9.85 & $0-162$ & 281 & doas \\
\hline$m-x y l\left(\mu g^{-3}\right)$ & 8.76 & 5.22 & $0-64$ & 254 & doas \\
\hline$p-x y l\left(\mu g^{-3}\right)$ & 12.29 & 9.27 & $0-37$ & 280 & doas \\
\hline Benzene $\left(\mu \mathrm{g} \mathrm{m}^{-3}\right)$ & 6.98 & 3.47 & $0-52$ & 269 & doas \\
\hline Styrene $\left(\mu \mathrm{g} \mathrm{m}^{-3}\right)$ & 8.05 & 5.07 & $0-102$ & 283 & doas \\
\hline Temperature $\left({ }^{\circ} \mathrm{C}\right)$ & 11.49 & 8.68 & $-10.1-29.6$ & 356 & TEI \\
\hline Solar Radiation $\left(\mathrm{W} \mathrm{m}^{-2}\right)$ & 210.19 & 129.49 & $5-782.5$ & 355 & TEI \\
\hline Pressure (mbar) & 945.08 & 10.78 & $935-963.1$ & 356 & TEI \\
\hline Relative Humidity (\%) & 68.76 & 18.13 & $38.5-98.9$ & 104 & TEI \\
\hline Wind Speed $\left(\mathrm{m} \mathrm{s}^{-1}\right)$ & 2.53 & 1.50 & $0.4-9.9$ & 356 & TEI \\
\hline $\mathrm{SO}_{2}$ Station $\left(\mu \mathrm{g} \mathrm{m}^{-3}\right)$ & 5.07 & 4.43 & $0-25.3$ & 268 & KOZANI \\
\hline $\mathrm{O}_{3}$ Station $\left(\mu \mathrm{g} \mathrm{m}^{-3}\right)$ & 28.80 & 10.99 & $5.8-53.2$ & 353 & KOZANI \\
\hline $\mathrm{NO}_{2}$ Station $\left(\mu \mathrm{g} \mathrm{m}^{-3}\right)$ & 12.34 & 4.27 & $0-25.6$ & 350 & KOZANI \\
\hline
\end{tabular}

Table 2. Pearson correlation coefficients of daily pollutants' concentrations and meteorological parameters from DOAS, ground surface and TEI stations

\begin{tabular}{|c|c|c|c|c|c|c|c|c|c|c|}
\hline & $\mathrm{NO}_{2}$ & $\mathrm{SO}_{2}$ & $\mathrm{O}_{3}$ & Toluene & $\begin{array}{l}\mathrm{m}- \\
\mathrm{xyl}\end{array}$ & $\begin{array}{l}\text { p- } \\
\text { xyl }\end{array}$ & Benzene & Styrene & $\begin{array}{c}\mathrm{SO}_{2} \\
\text { Station }\end{array}$ & $\begin{array}{c}\mathrm{O}_{3} \\
\text { Station }\end{array}$ \\
\hline $\mathrm{NO}_{2}$ & 1 & & & & & & & & & \\
\hline $\mathrm{SO}_{2}$ & 0.20 & 1 & & & & & & & & \\
\hline $\mathrm{O}_{3}$ & 0.06 & -0.26 & 1 & & & & & & & \\
\hline Toluene & 0.29 & 0.23 & -0.07 & 1 & & & & & & \\
\hline m-xyl & 0.38 & -0.02 & -0.18 & 0.44 & 1 & & & & & \\
\hline$p-x y l$ & 0.28 & 0.22 & -0.03 & 0.33 & -0.01 & 1 & & & & \\
\hline Benzene & 0.00 & -0.18 & 0.02 & -0.35 & -0.03 & -0.48 & 1 & & & \\
\hline Styrene & 0.11 & -0.03 & -0.40 & 0.28 & 0.16 & 0.20 & -0.12 & 1 & & \\
\hline $\mathrm{SO}_{2}$ Station & 0.14 & 0.89 & -0.30 & 0.35 & -0.02 & 0.25 & -0.34 & -0.08 & 1 & \\
\hline $\mathrm{O}_{3}$ Station & -0.16 & -0.26 & 0.63 & -0.40 & -0.16 & -0.36 & 0.26 & -0.32 & -0.42 & 1 \\
\hline $\mathrm{NO}_{2}$ Station & 0.21 & 0.35 & -0.41 & 0.47 & 0.21 & 0.17 & -0.20 & 0.17 & 0.49 & -0.59 \\
\hline
\end{tabular}


$\mathrm{SO}_{2}$ concentrations were generally low and follow the traffic flow in the city with maximum around noon. This is attributed to the low contribution from other sources like central heating during the cold period due to the use of district heating in the city.

The daily cycle of benzene and toluene presented a similar pattern with that of $\mathrm{NO}_{2}$ taking place in the photochemical formation of ozone. From Figure 4, high wind speed also helps in the dilution of these three pollutants around noon. Maximums occurred during night and morning hours possessing same sources of origin with $\mathrm{NO}_{2}$. Note that, toluene being more reactive showed a sharper distribution than benzene. Stagnant conditions during night time with low wind speed damp the vertical atmospheric movement allowing the pollutants to remain in the air for long hours with an average lifetime of 16 and 3 days for benzene and toluene, respectively (Singh et al., 1985). VOC's degradation mechanisms are complex but predominantly initiated by reaction with the hydroxyl radical.

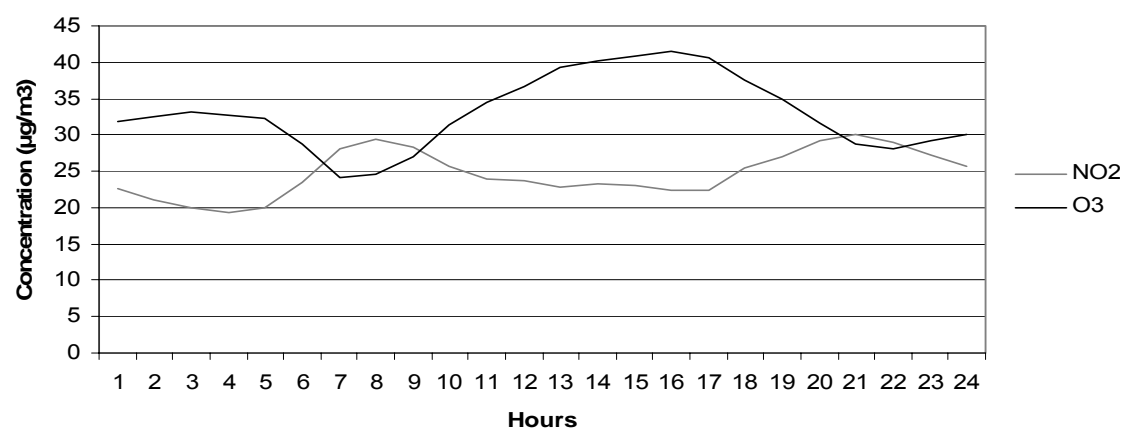

Figure 3. Annually averaged magnitude of hourly $\mathrm{NO}_{2}$ and $\mathrm{O}_{3}$ concentrations

The levels of $p, m-x y l e n e s$ did not follow any symmetrical pattern like the other VOCs due to xylenes' increased reactivity compared to toluene's ability to react. However, the capability of DOAS to measure xylene isomers involves uncertainties (Barrefors, 1996).

Photochemical age of air mass and fuel composition is estimated from the $\mathrm{T}$ (toluene)/ $\mathrm{B}$ (benzene) ratio. It has been known that toluene is more reactive than benzene and spontaneously removed on contact with hydroxyl radical in the presence of sunlight. The behaviour of this ratio is also affected by meteorological conditions. In Figure 4 is shown that during the three seasons with low wind the ratio $T / B$ is low during morning hours. Then, T/B is increased due to traffic emissions and atmospheric boundary layer mixing. The ratio has taken higher values during the cold period as in Seoul, Korea (Lee et al., 2005). The higher values of the ratio are attributed to less benzene contribution from evaporation especially under low temperatures.

Figure 5 describes the mean daily variation of ozone, benzene and temperature. In general, the two pollutants follow temperature increase but with a few discrepancies. This is mainly attributed to the complexity of the area in terms of topography, meteorological and urban conditions. In addition, one would not expect high correlation for example between ozone and temperature throughout a year due to temperatures increased variability. This would rather be the case for shorter periods of time under hot conditions and high ozone concentrations.

\section{CONCLUSIONS}

No violations of the European Union legislated limits have been detected for O3, NO2 and SO2 during the year of 2006. The annual mean of benzene $7 \mu \mathrm{g} \mathrm{m}^{-3}$ (Table 1) was above its European legislated limit (Directive 2000/69/EC, 2000) of $5 \mathrm{\mu g} \mathrm{m}^{-3}$ with the guidance that extra measures should be applied in order to reduce benzene by $1 \mu \mathrm{g} \mathrm{m}^{-3}$ every year until it reaches zero in 2010. Since EU has not guide value for toluene the measurements were compared against the World Health Organization (WHO, 2000) daily limit of $7.5 \mu \mathrm{g} \mathrm{m}^{-3}$. The most of the calculated mean daily toluene concentrations exceeded WHO's limit. 


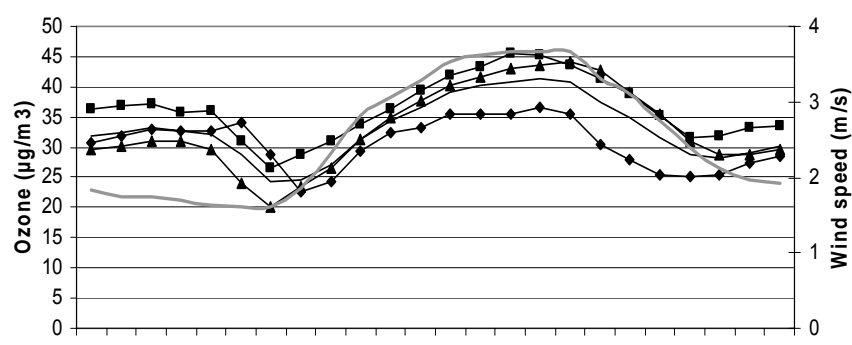

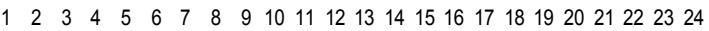
Hours

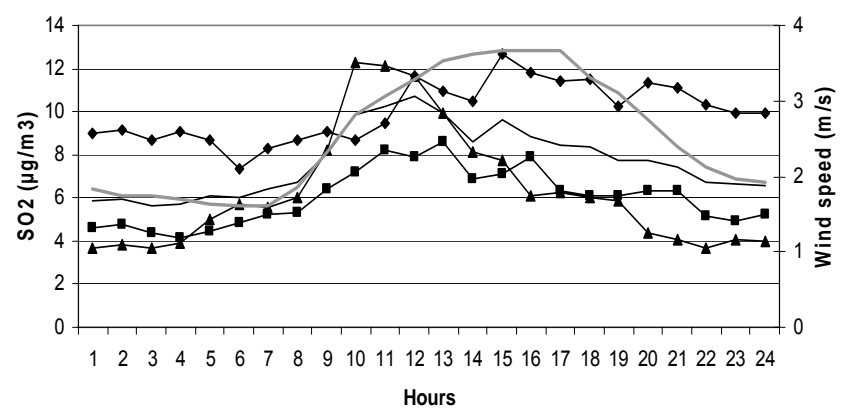

$\rightarrow$ Cold $\rightarrow-$ Transition $\rightarrow$ Hot $\_$Annual $\_$ws

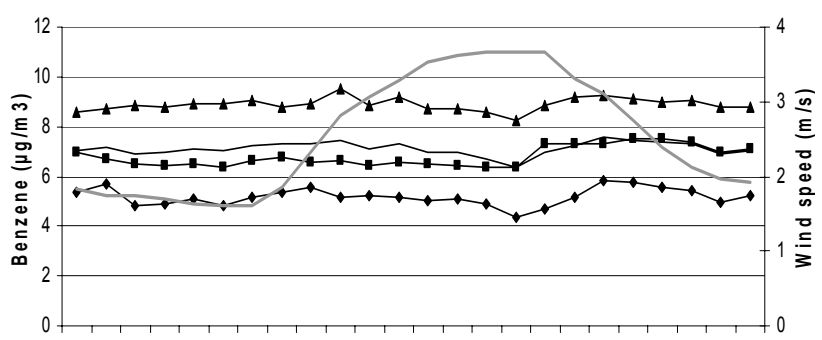

$\begin{array}{llllllllllllllllllllllll}1 & 2 & 3 & 4 & 5 & 6 & 7 & 8 & 9 & 10 & 11 & 12 & 13 & 14 & 15 & 16 & 17 & 18 & 19 & 20 & 21 & 22 & 23 & 24\end{array}$ Hours

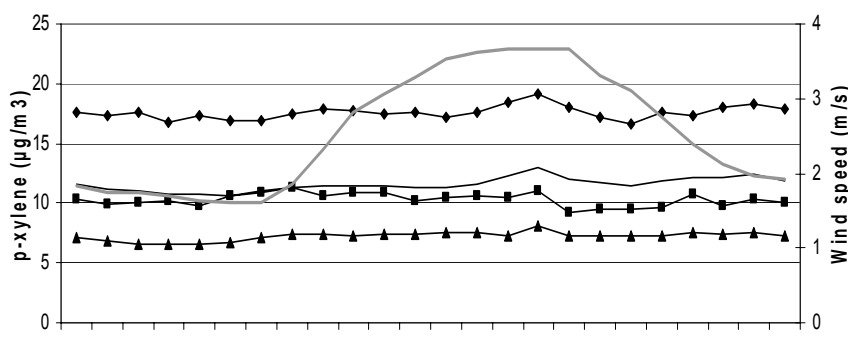

$\begin{array}{llllllllllllllllllllllll}1 & 2 & 3 & 4 & 5 & 6 & 7 & 8 & 9 & 10 & 11 & 12 & 13 & 14 & 15 & 16 & 17 & 18 & 19 & 20 & 21 & 22 & 23 & 24\end{array}$ Hours
- Cold - - Transition $\rightarrow$ Hot — Annual — ws

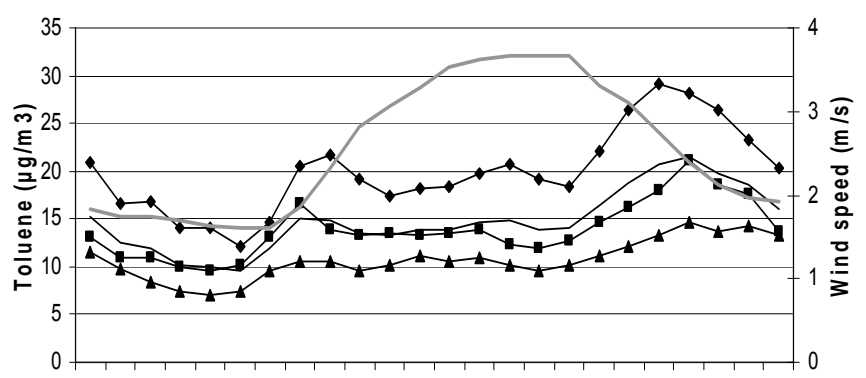

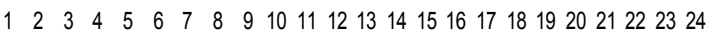
Hours

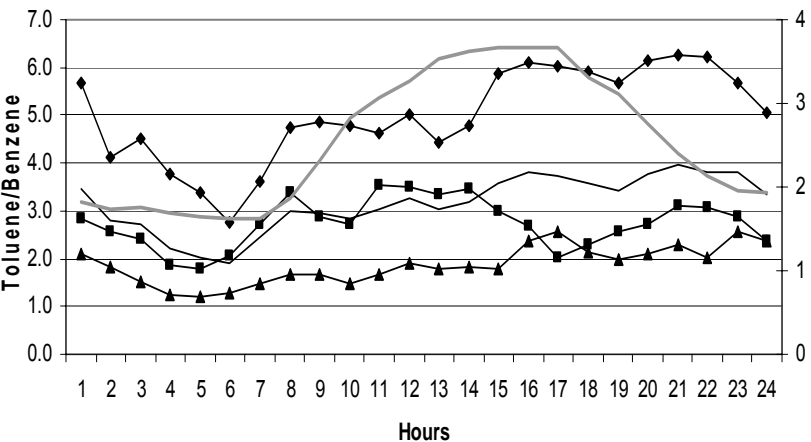

$\rightarrow$ Cold $\rightarrow$ Transition $\rightarrow$ Hot —Annual $\_$ws $\rightarrow$ Cold $\rightarrow-$ Transition $\multimap$ Hot $\_$Annual $\_$ws

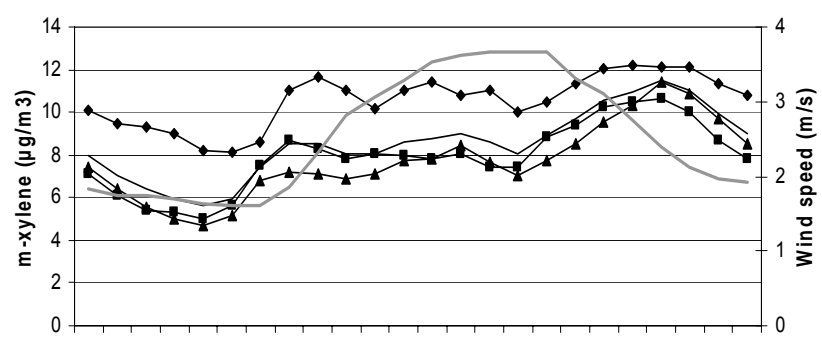

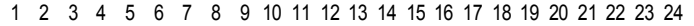
Hours

$\longrightarrow$ Cold $\rightarrow$ Transition $\rightarrow$ Hot — Annual —ws

Figure 4. Annually and seasonally averaged concentrations of pollutants and T/B against wind speed 


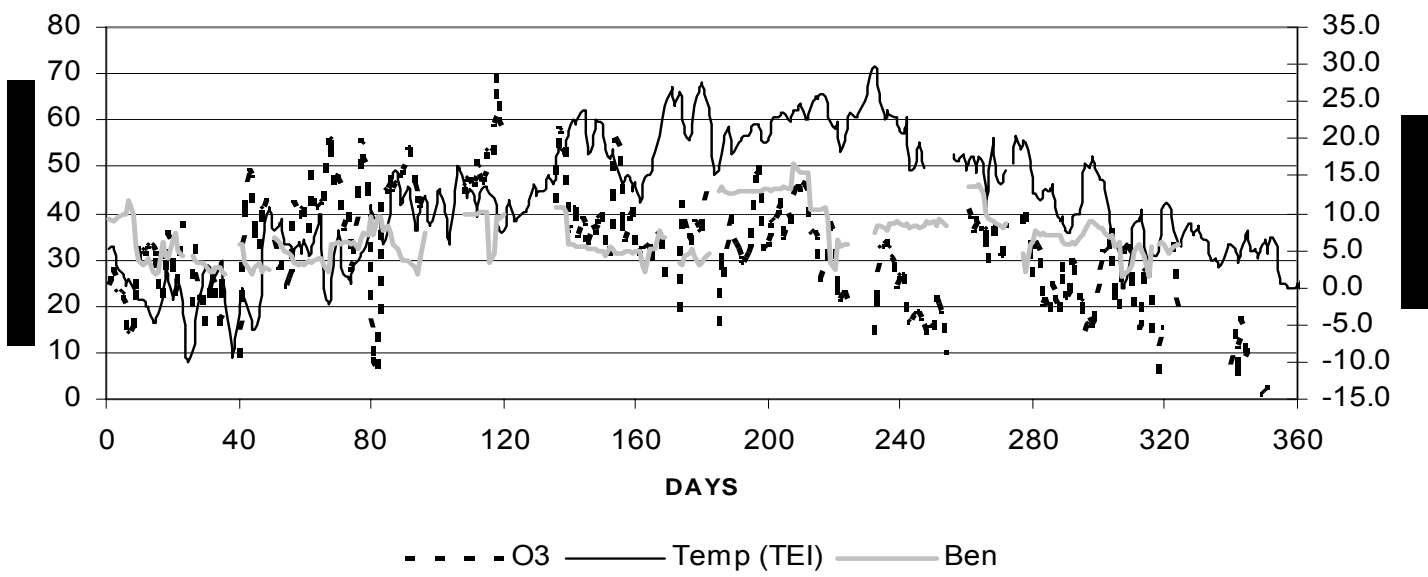

Figure 5. Mean daily fluctuation of ozone and benzene data vs temperature

The strong compatibility between DOAS and an in situ station has been verified. However, mesoscale conditions may influence the DOAS and surface station measurements due to distant sources impacts and background levels due to positive correlation of ozone and $\mathrm{SO}_{2}$ against wind speed. For benzene the case was clearer where contributions were attributed to traffic emissions. Similar Pearson correlation coefficients (Table 2) of the VOCs' and $\mathrm{NO}_{2}$ magnitude have also been observed due to their identical role in ozone's production.

\section{REFERENCES}

Barrefors G. (1996) 'Monitoring of benzene, toluene and p-xylene in urban air with differential optical absorption spectroscopy technique', The Science of the Total Environment, 189/190, 287-292.

Bernard S.M., Samet J.M., Grambsch A., Ebi K.L., Romieu I. (2001) 'The potential impacts of climate variability and change on air pollution-related health effects in the United States', Environmental Health Perspectives, 109, 199-209.

Chen K.S., Ho Y.T., Lai C.H., Chou Y.M. (2003) 'Photochemical modeling and analysis of meteorological parameters during ozone episodes in Kaohsiung, Taiwan', Atmospheric Environment, 37, 1811-1823.

Chiu K.H., Sree U., Tseng S.H., Wu C.H., Lo J.G. (2005) 'Differential optical absorption spectrometer measurement of $\mathrm{NO}_{2}, \mathrm{SO}_{2}, \mathrm{O}_{3}, \mathrm{HCHO}$ and aromatic volatile organics in ambient air of Kaohsiung petroleum refinery in Taiwan', Atmospheric Environment, 39, 941955.

EC (2000) Directive 2000/69/EC (13/12/2000) of the European Parliament and Council, Official Journal, L 313, pp 0012-0021.

Evagelopoulos V., Triantafyllou A.G., Zoras S., Diamantopoulos C. (2005) 'Differential optical absorption spectroscopy (DOAS) measurements in the city of Kozani' $20^{\text {th }}$ Chemistry Conference, loannina, Greece.

Kelessis A.G., Petrakakis M.J., Zoumakis N.M. (2006) 'Determination of benzene, toluene, ethylbenzene and xylenes in urban air of Thessaloniki, Greece', Environ Toxicol, 21, 440443.

Lee C., Kim Y.J., Hong S.B., Lee H., Jung J., Choi Y.J., Park J., Kim K.H., Lee J.H., Chun K.J., Kim H.H. (2005) 'Measurement of atmospheric formaldehyde and monoaromatic hydrocarbons using differential optical absorption spectroscopy during winter and summer intensive periods in Seoul, Korea', Water, Air and Soil Pollution, 166, 181-195.

Petrakis M., Psiloglou B., Kassomenos P.A., Cartalis C. (2003) 'Summertime measurements of benzene and toluene in Athens using a differential optical absorption spectroscopy system', Journal of Air and Waste Management Association, 53, 1052-1064.

Platt U., Perner D. (1979) 'Determination of nitrous acid in the atmosphere by differential optical absorption', Geophysical Research Letters, 6, 917-920.

Singh H.B., Salas L.J., Cantrell B.K., Redmont R.M. (1985) 'Distribution of aromatic hydrocarbons in the ambient air, Atnospheric Environment, 19, 1911-1919. 
Triantafyllou A.G., Kiros E.S., Evagelopoulos V.G. (2002a) 'Respirable particulate matter at an urban and nearby industrial location: Concentration and variability and synoptic weather conditions during high pollution episodes', Journal of Air and Waste Management Association, 52, 287-296.

Triantafyllou A.G., Kassomenos P., (2002b) 'Aspects of atmospheric flow and pollutants dispersion in a mountainous basin', Sc. of the Total Env, 297, 85-103.

WHO (2000) 'Air quality guidelines for Europe, European Series 91. Copenhagen, Denmark: World Health Authority Regional Publications, pp 1-198.

Wu B.Z., Chang C.C., Sree U., Chiu K.H., Lo J.G. (2006) 'Measurement of non-methane hydrocarbons in Taipei city and their impact on ozone formation in relation to air quality', Analytica Chimica ACTA, 576, 91-99.

Zoras S., Triantafyllou A.G., Deligiorgi D. (2006) 'Atmospheric stability and PM10 concentrations at far distance from elevated point sources in complex terrain: worst case episodes study', Journal of Environmental Management, 80(4), 295-302. 